Acta Universitatis Sapientiae, Philologica, 9, 1 (2017) 7-16

DOI: 10.1515/ausp-2017-0001

\title{
On the Advantages of Minority Condition in the Romanian-Hungarian Cultural and Literary Relations
}

\author{
Valentin TRIFESCU \\ University of Art and Design (Cluj-Napoca, Romania) \\ Department of Theoretical Disciplines \\ valentintrifescu@yahoo.fr
}

\begin{abstract}
This study analyses the way in which cultural and literary Romanian-Hungarian relations have evolved since World War I in the context of the rapport between majority and minority. Our aim is to analyze, from an interdisciplinary and diachronic perspective, the implications related to culture and identity of the process studied. We raise the problem of bilingualism and its manifestation at the level of bilateral cultural relations, in general, and literary criticism, in particular.
\end{abstract}

Keywords: collective identities, literary criticism, Transylvania, minoritymajority, regionalism.

Paradoxically, the ones that lost may be considered winners (or the winning side) and the ones that won, losers. This is the formula that summarizes the rapport between the advantages and disadvantages of the historical events of the twentieth century, especially the two World Wars, on the cultural and literary Romanian-Hungarian relations, in general, and the Transylvanian case, in particular. Certainly, our approach is diachronic. We took no interest in the exceptions, gaps or breaks, but in the developments of the cultural phenomenon, its metamorphoses and possibilities to endure through time.

With much visionary spirit, in a Transylvanian-Hungarian society going through collective identitarian depression of identity caused by the passage of Transylvania under the administration of Romanian authorities in Bucharest (Olcar 2011, 10), the reformed priest and publicist Dezső László (1904-1973) optimistically described the cultural advantages of minority life. To the Hungarian scholar, the new political and administrative realities of interwar Transylvania were an occasion for Hungarian culture to flourish beyond a national state, under other forms and submitted to conditions different than before. Far from accepting 
the idea of minority culture, submissive to the new Romanian dominant culture or incapable of witnessing the dissolution of the Hungarian national specificity, László militated for a new form of cultural manifestation of Transylvanian Hungarians centred on the ethnic condition of minority. In the Calvinist vision of the reformed priest, the minority status of Transylvanian Hungarians may be accepted and dealt with via a process of evaluation and acknowledgement of specific values, as well as acceptance of one's historical destiny. In this way, László was convinced that the Hungarian people may live and create beyond the political borders of the Hungarian state $(2003,126)$.

For László, there were no fatal consequences for the Transylvanian Hungarians' culture and identity after World War I; on the contrary, it was an occasion to develop a new life meant to bring benefits not only to the ones that had the status of minority, but also to Hungarians on the whole. Thus, minority condition has become a quality, not a flaw, a chance to enrich the national vein by means of contacts and exchanges with alterity. Despite the fact that the old Hungary was broken into pieces which were given to other national states, László believed in the unity of soul and destiny for Hungarians that crossed political borders (2003, 127-129).

The ideas developed by the Hungarian priest and publicist were expressed in the context of ideas triggered by the manifesto signed in 1921 by Károly Kós (18831977), The Shouting Voice. To the Hungarians of Transylvania, Banat, Partium and Maramureş! In this seminal text, the Transylvanian architect and cultural figure embarked on the tough mission of encouraging the Hungarian population of the Romanian state, militating for the continuation of the cultural life and Hungarian identity by work, dignity, character and power to resist (Kós 2003, 4547). Starting from the idea of an "eternal" Transylvania - which existed before the Treaty of Trianon and afterwards - that implied a distinct consciousness, culture and moral obligation on the Hungarians from Transylvania, Kós pleaded for an integration of Hungarians into Romania by work, with the condition of respecting Hungarian national autonomy based on the historical past.Thus, the Hungarian minority will continue to produce cultural and material values with national/regional specificity whereas Romania will benefit from a cultural and material creation that it has not had before 1918 (Kós 2003, 49-50).

The interwar generation of Romanian intellectuals from Transylvania who studied Hungarian literature and the cultural and literary relations between Romanians and Hungarians were especially formed within higher education institutions in Budapest or other cities of the Dual Monarchy. Before World War I, all Romanian intellectuals had a minority ethnic status and studied in Hungarian or German at the university. So, even if the political context changed, their cultural inheritance and intellectual habit persisted throughout their lives. Thus, their minority condition became the one of a majority after 1918 without 
their departure from the intellectual and cultural environment in which they were raised. This generation was marked by the personality of Ion Chinezu (1894-1966), author of the first renowned synthesis on Transylvanian Hungarian literature. Aspects of Transylvanian Hungarian Literature (1919-1929), published in Cluj-Napoca in 1930, had a positive echo in the Hungarian press due to its documentary and scientific value. Moreover, Chinezu's paper was considered by the critics of the time and by critics today [!] (Pomogáts 2002, 46; Nagy 2015, 11) the best systematic analysis of the Transylvanian Hungarian culture of the first decade after the Great Union; his performance could not even be equalled by the ethnic Hungarian literary critics of the time (Balotă 1981, 444).

Chinezu's book tackles the (trans)formation period of Hungarian literature due to the new political realities. The university professor György Kristóf (18781965 ) felt the same need for analysis and published the volume of papers Ten Years of Hungarian Literature in Romania (Pomogáts 2002, 39-40). The passage of the intra-Carpathian region under the administration of the authorities of Bucharest freed the cultural life of Transylvanian Hungarians from the pressure of centralism exerted by the Hungarian capital. If before 1919 great culture had only been achieved in Budapest, afterwards the regional culture of Transylvania started to become much more active, consistent and original. Particularly marked by the group of writers gravitating around the Cluj review Erdélyi Helikon that gave them conceptual unity, Transylvanian Hungarian literature was attracted by local or regional themes, overcoming the pre-war conflictual duality between traditionalists and modernists. Chinezu was the witness and the interpreter of the deprovincialization process of Transylvanian Hungarian literature during paradoxical times, when Hungarians had the status of minority (Balotă 1981, 447-448). In other words, a process of literary and cultural centrality of periphery was achieved in Transylvania, despite its position on the edge of a centralized political system; it won its aesthetic autonomy by artistic creation with regional specificity accomplished in a language different from the official one.

After World War I the political centre was shifted from Budapest to Bucharest, yet Transylvanian Hungarian literature took a different path. For Hungarians, Bucharest was less attractive than Budapest because it was not loaded with the same national purport. Developing in a medium other than the monopolizing and dominating one of Hungarian culture, Transylvanian Hungarian literature had the chance of building a stronger national specificity within Romanian culture and distinguished itself from it particularly via the language. Therefore, Ion Chinezu defined well the status of provincial Hungarian literature during the Austro-Hungarian period as well as the new conditions that facilitated the development of an original and qualitative Hungarian literature in Transylvania: 
During these decades in which the aim of Budapest was to achieve political and cultural unity with the death of the soul in highly traditional regions as the price to be paid, we cannot speak of a Transylvanian Hungarian in the sense we do nowadays, i.e. of a literature defined by local content, the tendency to state a specifically regional character or at least the external criterion of a more reputed literary group. New talents felt the need to be acknowledged by the capital and the few writers that insisted on remaining here such as the gifted short story writer István Petelei (1852-1910) ended by almost being forgotten by the Hungarian public whose attention and taste were definitely conquered by the ruling of Budapest. / However, things have changed since Transylvania joined Romania. The new state formation also brings along several new problems for the Hungarians, imposing a spirit of cooperation, along with a radical change of mentality and the the necessity to find the appropriate attitude to deal with the new conditions. It is only now that Transylvania is discovered as a topic for literature, in the true sense of the word. (Chinezu 1930, 6) ${ }^{1}$

Regionalism was the path for Transylvanian Hungarian literature to build its own identity in terms of regional geography and history. This concentration on its own values made possible the distancing from leveling canonical models given by the official literature of the Centre. Transylvanism ${ }^{2}$ provided local means of communication (especially via the cultural reviews of Transylvania's cities) between Romanians and Hungarians without external or distant (inter)mediation. The main promoters of Transylvanism were Hungarian intellectuals who militated for a closer and more genuine relation between Transylvanian Romanians and Hungarians. In this sense, the historian and literary critic Béla Pomogáts argued that

The writers for the review Erdélyi Helikon, far from considering the cultural closeness of Transylvanian ethnicities a political compromise, sincerely believed in the power of the idea of Transylvanism, along which national reconciliation and literary cooperation became possible [...]. The representatives of the literary group writing for Erdélyi Helikon took on this noble role, purporting to achieve solidarity between Hungarian, Romanian and German literature from Transylvania. (2002, 32-33)

The minority condition afforded the Hungarians from Romania this "soft" openness towards alterity as before World War I the actions meant to Hungarize

1 The translations from Romanian specialist literature are my own throughout the article - A-M. P.

2 Regionalistic movement in Transylvania with important political, cultural and artistic implications; mostly popular during the interwar years among Hungarian, Saxon and Romanian intellectuals. 
Romanians represented a true "hard" state policy. Therefore, during the interwar years Romanian intellectuals with regionalistic views were less enthusiastic about promoting cultural Transylvanism and particularly reluctant to the likely political (revisionist) implications of this movement of ideas (Todor 1983, 303-304). At the end of the 1930s, when the nationalist and xenophobic right party rose, Transylvanism lost a significant part of the support of Romanian intellectuals, further maintaining the imbalance in availability for intercultural dialogue and mutual cognition (Pomogáts 2002, 46; Dávid 2012, 157). The revival of Romanian-Hungarian cultural relations and, as Pomogáts put it, "the rebuilding of bridges" were only accomplished after World War II; consequently, between 1945 and 1948 the literary and cultural cooperation between Hungarians and Romanians was extremely fertile $(2002,68)$.

An explicit affiliation with cultural or literary regionalism was avoided by the Romanians because the word itself was compromised or could have been compromising (Trifescu 2011, 370). Against this background, the literary critic Alexandru Dima coined the alternative concept of creative localism, which aimed at stimulating the rise of a Romanian literature inspired by the current living realities of the place. In the opinion of the literary critic, not the general vague approximate and stereotypical features of the province but the place and its specific identity needed exploring in literature. The approach was a plural, mosaic, fragmentary and broken one with many local and zonal peculiarities (Manolache 2006, 53). This (alternative) form of manifestation of Romanian cultural/literary regionalism is actually, in a paradoxical manner and to a great extent, an anti-regionalist regionalism. The localist form(ula) of literary manifestation was considered sufficiently intense to destabilize the cultural and political unity of the young Romanian state. However, cultural regionalism was deemed to be a movement with a high destabilizing potential and no clearly defined consistency which could be explored for political, revisionist interests. In this sense, Dima believed that

as far as the formula of 'creative localism' is concerned, we need to accept from the beginning that it is neither an absolute equivalent for the more frequently used expression 'cultural regionalism,' nor does it have its notional coverage. 'Localism' makes theory and militates on the basis of an immediate, living and concrete socio-geographic reality of the 'place,' whereas regionalism is founded on the more general and vague existence of the 'region,' hence its unreality. Finally, the term 'regionalism' acquired such ill fame by the mixture of its elements of centrifugal politics that its elimination from the sphere of culture would be more than desirable. $(1935,1)$

It is worth mentioning that creative localism, coined by Dima, as an alternative theoretical reply to both the regionalist literature of Transylvania and the centralist 
one of Bucharest, does not block Romanian-Hungarian literary relations and the openness to alterity. In the scenographic horizon marked by the geography of various Transylvanian counties and lands, the Romanian literary critic also traces the vertical axis of literatures with regional/local specificity which makes them thorough and legitimate. Therefore, it may be stated that history brought Hungarians and Romanians together in time, their interaction leading to original and autonomous Romanian literary productions created outside any gravitational influence of centralism.

Creative localism has always dominated Romanian culture; in any quantitative and qualitative case, localist literary movements scored better than centralist ones. In this respect, we can bring into play a series of characteristic literary moments, illustrating the idea that cultural centres generally did not coincide with the political ones. The first Romanian book, The Lutheran Catechism, was printed in 1544 in Sibiu. Deacon Coresi's numerous printings were not published in the capital of Transylvania or Wallachia, but in Braşov, where he found his refuge in the sixteenth century. (Dima 1935, 7)

In spite of the fact that Dima's view on writing literature draws on a national Romanian vein, it is a minority one due to its anti-centralism. We could argue that Dima had the mindset of a Romanian minority figure within the Romanian culture itself. Through his attitude, similar to the one of regionalist Hungarian ethnic figures, the Romanian literary critic opposes the (literary, cultural and political) centre represented by Bucharest. The intention was that of nonassimilation, non-enrolment, autonomy, dissidence and liberation with respect to levelling centralism from an aesthetic, ethical and identity-related viewpoint. Starting from Virgil Nemoianu's theory of the secondary and the phenomenon of recessivity described by Mircea Florian, the literary historian Gheorghe Manolache argued that "whether 'transparent' or not, the literary province remains a secondary structure and - precisely because of the tension it maintains with the centre [Bucharest!] - dependent on the way 'hard thought' operates. Even if they do not annihilate each other, the province and the literary centre do not fuse to achieve cultural synthesis!” $(2006,15)$.

We could say that on the long term, after almost one hundred years from the end of World War I, Hungarian-Romanian literary and cultural relations embarked on a journey without any possible way of return. From the beginning, the process of linguistic and cultural compatibility of Transylvanian Hungarians with the new political, administrative and cultural realities of Greater Romania was a slow and difficult one; in the end, Hungarian intellectuals became an actively and functionally integral part of the Romanian literary and cultural organism. In this context, the researcher Enikő Olcar claimed that 
cultural relations between various ethnicities were hardened by the fear of communicating with the "other," taking cover in an invented shell with a defending mechanism of its own for the universe in question. Then, a great part of Hungarian literary figures started to master the Romanian language, carried out excellent translations, reviewed books and wrote articles on Romanian cultural life for Romanian periodicals and militated for a closer cultural relation and a better acquaintance of the two. Knowledge of the Romanian language by the Hungarian ethnic minority remained a basic requirement for a continuing peaceful development of their own culture and writing in Hungarian which led to remarkable progress of Hungarian literature and culture. $(2011,15)$

As far as the Romanian part is concerned, there can be noticed a considerable diminution of the number of Romanian intellectuals proficient in Hungarian and still interested in Hungarian literature and the cultural relations between the two ethnic groups of Transylvania, the Romanian and the Hungarian one. Despite the ideological appearances and prejudices or dominating political correctness nowadays, communist Romania witnessed the publication of extremely important volumes on the literary and cultural Romanian-Hungarian relations which significantly overcome qualitatively and quantitatively the Romanian historiographic production from the past years. The activity of Kriterion Publishing House in Bucharest needs to be particularly emphasized in this sense. However, along with the death of several Romanian intellectuals such as Avram P. Todor (1899-1978), Gavril Scridon (1922-1996) and Nicolae Balotă (1925-2014) - born before 1919 or during the interwar years in a society in which Hungarian was still a language of culture for the Romanian elites of Transylvania -, who dealt with the literary and cultural Romanian-Hungarian relations, the popularity of this topic of research started to decline at an alarming rate. Its last active Romanian representative has been Mircea Popa (born in 1939).

It can be assessed that the study of Romanian-Hungarian literary relations (with all its cultural implications) has become an essentially Hungarian field of interest for the past couple of years as the Romanian majority no longer have access to alterity because they do not know the language. Thus, the study of Romanian-Hungarian relations willy-nilly has became a topic monopolized by the Hungarian minority, and there are no Romanian papers to compete with the recent scientific contributions of researchers such as Enikő Olcar (born in 1980), Enikő Pál (born in 1983) or Imola Katalin Nagy (born in 1975). We are witnessing a process of impoverishment of the Romanian culture because "not knowing the other is not knowing one's own identity!" (Trifescu 2015, 733); the only possibility of dialogue between the two cultures is a "second hand" one mediated via the filter of translations from Hungarian into Romanian or from Hungarian into international languages. 
The age of "no interpreters" (Beke 1972) in which almost all intellectuals were bilingual has passed; the age of constructive or degenerative polemics between two national opposite sides that knew each other well is gone (Trifescu 2015, 732-733), not to mention the period of "rebuilding bridges" from the communist period (Pomogáts 2002). As a manifestation of the impossibility to have a real intellectual dialogue, the Hungarian minority need to express themselves in Romanian to be understood. The three eminent pieces of research published in the "language of the other" are representative in this sense (Olcar 2011; Pál 2014; Nagy 2015). At present, we are witnessing the dawn of an entire Transylvanian cultural tradition in which openness towards dialogue, plural thought and knowledge of the other only live through the Hungarian minority in Romania. However, in a near future, not knowing the other and the inability of cultural dialogue will silence Romanian culture, pointing at its inability to understand alterity. On the other hand, it will show great spiritual and intellectual impoverishment specific to the "carcase man" in an era of homogenized masses with no specific traits (Ortega y Gasset 2002).

Translated by Ana-Magdalena Petraru

\section{Works Cited}

Balotă, Nicolae. 1981. Scriitori maghiari din România (1920-1980). [Hungarian Writers in Romania (1920-1980).] Bucureşti: Kriterion.

Beke, György. 1972. Fără interpret. Convorbiri cu 56 de scriitori despre relațiile literare româno-maghiare. [No Interpreter. Talks with 56 Writers on RomanianHungarian Literary Relations.] Bucureşti: Kriterion.

Chinezu, Ion. 1930. Aspecte din literatura maghiară ardeleană (1919-1929). [Aspects of Transylvanian Hungarian Literature.] Cluj-Napoca: Editura Revistei "Societatea de Mâine."

Dávid, Gyula. 2012. "Transilvanismul. Câteva considerații în legătură cu conceptul şi prezențele lui în trecut şi prezent." ["Transylvanism. Several Considerations on the Concept and its Past and Present Occurrences."] In Austrian Influences and Regional Identities in Transylvania, ed. François Bréda, Valentin Trifesco, Luminița Ignat-Coman and Giordano Altarozzi, 148158. Bratislava - Frauenkirchen: AB-ART - Grenzenlose Literatur.

Dima, Alexandru. 1935. "Localismul creator - definirea şi justificarea lui." ["Creative Localism - its Definition and Justification."] In Activitatea Grupării Intelectuale "Thesis" pe anul 1933-1935 [Activity of the Intellectual Group "Thesis" during 1933-1935], 1-8. Sibiu: "Cartea Românească." 
Florian, Mircea. 1983. Recesivitatea ca structură a lumii. [Recessivity as World Structure.] Vol. 1. Bucureşti: Eminescu.

Kós, Károly. 2003. "Glasul care strigă. Către maghiarimea din Ardeal, Banat, Ținutul Crişurilor şi Maramureş!” ["Shouting Voice. To the Hungarians of Transylvania!”] In Maghiarii din România şi etica minoritară (1920-1940) [Hungarians of Romania and Minority Ethics (1920-1940)], eds. Lucian Nastasă and Levente Salat, 45-51. Cluj-Napoca: Centrul de Resurse pentru Diversitate Etnoculturală.

László, Dezső. 2003. "Darurile vieții minoritare.” [“Gifts of Minority Life.”] In Maghiarii din România şi etica minoritară (1920-1940) [Hungarians of Romania and Minority Ethics (1920-1940)], eds. Lucian Nastasă and Levente Salat, 126135. Cluj-Napoca: Centrul de Resurse pentru Diversitate Etnoculturală.

Manolache, Gheorghe. 2006. Resurecția localismului creator. O experiență spirituală în Mitteleuropa provinciilor literare. [The Rise of Creative Localism. A Spiritual Experience in the Mitteleuropa of Literary Provinces.] Sibiu: Editura Universității “Lucian Blaga.”

Nagy, Imola Katalin. 2015. Interferențe culturale româno-maghiare. [RomanianHungarian Cultural Interferences.] Cluj-Napoca: Scientia.

Nemoianu, Virgil. 1989. Theory of the Secondary. Literature, Progress and Reaction. Baltimore: Hopkins University Press.

Olcar Szilaghi, Enikő. 2011. Relații literare şi culturale româno-maghiare în perioada interbelică. [Romanian-Hungarian Literary and Cultural Relations in the Interwar Period.] Doctoral thesis, ed. Mircea Popa. Alba Iulia: Universitatea "1 Decembrie 1918."

Ortega y Gasset, José. 2002. Revolta maselor. [Revolt of the Masses.] Second edition, trans. Lupu Coman. Bucureşti: Humanitas.

Pál, Enikő. 2014. Influența limbii maghiare asupra limbii române. Perioada veche. [The Influence of Hungarian on Romanian. The Old Period.] Iaşi: Editura Universității “Alexandru Ioan Cuza.”

Pomogáts, Béla. 2002. Reconstruirea podurilor (maghiarii şi românii). Studii şi articole. [Rebuilding Bridges (Hungarians and Romanians). Studies and Articles.] Trans. and notes by Anamaria Pop, foreword by Gabriel Andreescu. Sfântu Gheorghe - Budapesta: Pont fix -Pont.

Scridon, Gavril. 1996. Istoria literaturii maghiare din România (1918-1989). [History of Hungarian Literature in Romania (1918-1989).] Cluj-Napoca: Promedia Plus.

Todor, Avram P. 1983. Confluențe literare româno-maghiare. [RomanianHungarian Literary Confluences.] Ed., notes and foreword by Gyula Dávid. Bucureşti: Kriterion. 
Trifescu, Valentin. 2011. "Transilvanismul lui Iancu Azapu.” [“Iancu Azapu’s Transylvanism.”] Anuarul Şcolii Doctorale "Istorie, Civilizație. Cultură” no. V: 369-379.

Trifescu, Valentin. 2015. "Glose pe marginea cărții Influența limbii maghiare asupra limbii române. Perioada veche." ["Glosses on the Book The Influence of Hungarian on Romanian. The Old Period."] Terra Sebus. Acta Musei Sabesiensis no. VII: 732-739. 